\title{
Urban sustainability challenges: democracy and spatial injustices in modern Tunisia
}

\author{
A. Mahmoud \\ National School of Architecture and Town Planning, \\ Carthage University, Tunisia
}

\begin{abstract}
In this paper, the author addresses spatial injustices in Tunisia, and seeks to understand to what extent social and territorial inequalities could hamper democracy. Indeed, urban disparities and social anomalies such as informal sector, terrorism, unemployment, and unsustainable development policymaking threaten vulnerable ongoing democratic processes in modern Tunisia.

The author described and analyzed the previous urban planning processes, which had been undertaken by the nation's mono party state since independency. The top-down development policies implemented up until now in Tunisia entailed the deepening of the large gap between coastal and inland areas. In fact, the former benefitted from their location across the seashores, and their proximity to the central power and economic growth. However, the latter had been left behind due to their austere geographical neighbourhood (e.g. desert, drought, lack of livelihood...).

Urban disparities and social inequalities in Tunisia join in a networked society where local and global unfold in a globalized world of flows and nodes. Local societies are subsystems within a global neo-liberal capitalist system. Hence, the current social movements triggered in Tunisia are not cyclical. They are amongst global social networked movements. Terrorism, pollution, and inequalities are not per se, but they are the negative results of a myriad of factors: economic, politics, cultural, emotional, social, and urban morphologies syndromes.

Our method is theoretical drawing into literature review of documents (i.e. town planning documents, reviewed and un-reviewed papers on sustainability, democracy, territorial and social inequalities in Tunisia since independency. Data
\end{abstract}


collected on the topic are worthy of the analyses but we tried to make sure of their credibility. Our objective is to demonstrate that without a sustainable urban governance development, democracy faces many hindrances and could be undermined in Tunisia.

Keywords: challenges, democracy, injustices, space, sustainable, Tunisia.

\section{Introduction}

Sustainability is often confined to environmental dimensions. It is, indeed, a multidimensional concept: ecological, economic, and social. Urban and social disparities are anthropogenic in the way that they stem from human actions on nature. They are socially and culturally constructed. So we highlight that sustainable urban development couldn't be achieved regardless of assessing the existing urban syndrome, and spatial injustices entailed by previous urban policies in modern Tunisia.

Our conceptual framework needs to be clarified through epistemological point of views. Inasmuch, theory is compulsory for any empirical or theoretical study, we distinguish between inequality and injustice. The former means disparities and gaps entailed by economic, social, and political processes. The latter, is related to the legal laws, statutes, citizenship, and the right to the city. Spatial phenomenon shapes social reality. Talking about spatial injustice refers to geography and denies social injustices, which are grounded in geographic space. Spatial injustice as related to democracy, equality, citizenship, and civil rights (Soja [1]) has new meanings today in the new global neo-global capitalist liberal context due the deepening of gaps between haves and have-nots.

First, we can postulate that sustainability is ecological, economic, and social. Then we analyze the phenomenon as a total social fact encompassing all those dimensions.

Second, the urban and social gaps in Tunisia were entailed by a complexity of factors intermingling (i.e. geographic, historic, economic, social, and cultural). The Nation-State implemented town-planning policy-making that didn't achieve spatial and territorial equalities.

Third, lack of resources in energy, regional and local conjunctures constitute hindrances against sustainable development in Tunisia. Accordingly, the deepening of the socio-spatial gaps could hamper the vulnerable democratic process in modern Tunisia.

Multilevel governance based on fairness, justice, and accountability is required in order to fulfil and achieve the revolution objectives in Tunisia.

\section{Bisectorial economy and beyond}

The Tunisian economy is still vulnerable due to its structural foundations. Inasmuch, Tunisia - as any other country - is amongst a global network, the conception of two-tiered economy is not relevant enough to understand economy syndrome in Tunisia. 
In 1973, the first master urban planning plan was undertaken by Town Planning Direction (Group Eight) along with the new liberal economic policy led by Hedi Nouira (Deputy Prime Minister at that time) in the aftermath of the State Capitalism failure in 1969. The subsidies abolition decision triggered revolts all over Tunisia ( $3^{\text {rd }}$ January, 1984). The subsidy funds had been created by decree since French protectorate on $28^{\text {th }}$ June 1945 . It consisted to protect Tunisian households against high rising prices of cereal products. Its objective bypassed the protection of household's consumption of power, it also aimed to guarantee the minimum wages for agricultures in difficulties. Afterwards, the subsidy funds encompassed more food needs (i.e., milk, meat, energy).

The well-being has been conceived in terms of GDP growth only. Then, we wonder why Tunisian and Egyptian economy growth were the best in the MENA and Africa though, uprising sparked in both countries? According to Stiglitz [2] (Nobel Prize Economist), "the well-being shouldn't be limited in GDP growth". It also has to take into consideration other dimensions (i.e. gender, health, education, governance). Otherwise, we still remain in the Kenysian and Fordist conceptions criticized in the sixties by many scholars as Marcuse [3] did in his book entitled: "the one-dimensional man", considering the new consumption society as more repressive and alienating the human being, and so did Eric Fromm in America in talking about 'Revolution of Hope'. For Stiglitz, the wellbeing calculation must take into account the following: "Material living standards (income, consumption and wealth), health, education, personal activities including work, political voice and governance, social connections and relationships, environment: present and future conditions, insecurity of economics as well as physical nature. All these dimensions shape the people's well-being, and yet many of them are missed by conventional income measures" (Stiglitz et al. [4]).

In short, spatial inequalities are social and vice versa. Territorial inequalities in Tunisia are shaped by policy makings and several social and urban actors strategies.

\subsection{Urban gap in Tunisia}

Urban planning documents: PAU (Urban Spatial Planning), SDAT (Master Plan of Town and Country Planning), CU (Urbanism Code), PRAT (Regional Master Plan of Urban Planning) didn't fulfil urban policy making objectives. However, the territorial inequalities deepened sharply in Tunisia.

The results of the parliamentary elections held on Sunday, $26^{\text {th }}$ October, 2014 draws a political map where the Islamist party is still popular in the areas of its main historic origins, and inland of the country. The central and south-western governorates feel excluded by the modern nation-state. Nidaa Tunis had the lion's share of votes in northern areas of Tunisia. Even though, in the central west, it shares its votes quite equally with Ennahdha.

The Islamist party didn't fulfil its promises and then anger aroused among voters. In the South, many Ennahdha leaders are issued from there, and the sympathy to the Ennahdha could be explained also by some historic collective memory, and the past political conflict between Habib Bourguiba and Salah Ben 
Youssef (political opponent of Bourguiba about Tunisia's full independency from France's protectorate). Territorial inequalities play a key role in the present political map of Tunisia.

In their studies on inequalities in Tunisia, Kriaa et al. [5] argued that inequalities between regions and delegations in Tunisia are correlated to neoliberal openness policy making. In fact, the location of foreign companies settled thanks to the 1972 law was an incentive to foreign development investment. FDI may benefit relatively to hinterland-disadvantaged areas. The authors highlighted that "foreign companies may choose to settle in developed areas where accommodation and facilities exist. Then inequalities between delegations increased".

The coastal areas benefited from development policies. More than $60 \%$ of investments are concentrated on littoral areas, mainly Tunis and the North East and the South East. The new technologies of information and communication, cosmetic, tourism and refined commerce (e.g. export industries, textile) are located in the Eastern littoral areas (Belhedi [6]). During an important forum held in Tunisia in September 2014 many investors from across the world attended the forum and committed to invest in Tunisia (i.e. economic city in Enfidha nearby Sousse, financial harbour in Tunis, to name but a few). Would those projects be achieved in the short-run? Those mega projects would guarantee around 250,000 job opportunities. In fact, much resilience exists which could hamper foreign investment in Tunisia (e.g. land planning documents, growing terrorism, governance).

In the same way, continuing to invest in the littoral would deepen more and more the territorial and social gaps between coastal areas and hinterland (Dlala et al. [7]) and the urban syndrome would likely worsen furthermore. It seems that the same tendency consisting of doing "city for profit persists instead of making cities for people" (Marcuse et al. [8]).

\section{Informal activities and territorial hiatus}

Since the seventies, social movements were growing (26 January, 1978) and in the eighties culminating in economic crisis ( $3^{\text {rd }}$ January, 1984) when the government decided to lift subsidies on foods; the president Bourguiba, at the beginning of the end of his reign, resiliated the government decision in order to appease the people's outrage. The miner basin movements (January, 2008) against recruitment by clientilism, obedience to the regime was led by bottom trade unions in Sfax-Gafsa Company and in the west of the country, Gafsa. In the summer of 2010, in the border town of Ben Guerdane, the informal traders and unemployed youth of the region opposed the authorities, which decided to close the Ras Jedir Gate. It is the main means of living of many families in the area.

\subsection{Areas of chaos}

The urban vacuum or what we can call 'space of chaos' (Balandier [9]) characterizing south-eastern, south-western, central-western and north-western 
areas is an area of poverty, social exclusion and marginalization due to previous development policies led by the Nation State. In the south-east, Jeffara area (south east of Tunisia) is arid where rainfall doesn't exceed $200 \mathrm{~mm}$ per year, pastoral activities (camels, livestock) is the most important livelihood in history, agriculture represents around 17.3 of useful agricultural land (Boubakri and Nouri [10]). Many of the Jeffara inhabitants emigrate to north Tunisia (Tunis, mainly), to Libya or to Europe where they exert some activities traditionally well-known in the area Ftä̈ri (doughnuts maker), bakery, Hammas (dried fruit seller).

In fact, local populations living across borders, and even in many towns and villages, are occupied by about $42 \%$ informal commerce. A few barons became the richest; other intermediaries gain their livelihood through informal commerce with Libya, and Algeria. We can find those informal activities in a broader worldwide economic network (e.g. US and China commerce deals) amongst economic competitions between the super powers of the world. Wholesalers in Libya import goods from China, India, and Turkey and stock them in warehouses. Retailers from Ben Guerdane and others buy those merchandises through money exchangers, cambists, who provide Libyan currencies with interest - sometimes banks - make the operation. The benefits of this commerce are $50 \%$ or more when they are free of custom taxes. The main border station controls are: Jendouba and Kef governorates in the North West, Kasserine in the Central West, Bouchebka, and Tozeur in the South West, Ras Jedir in Ben Gardane South East, Wasin, and Mashhad Salih in Tataouine, South East of Tunisia (Kartas [11]). Some connivance usually exists between customers, security agents, and smugglers.

The United Nation's Habitat report confirmed those practices as follows: "Such groups can become involved in acts of communal violence in regions of Asia and Africa. On the other hand, police, especially in Africa, have found themselves in situations where it may make tactical sense to develop ongoing relationships with these groups" (UN-Habitat [12]).

In the north-western regions, informal activities are growing among the local unoccupied population. In these areas, agriculture activities are the most important ones. Though, some problems of water costs, natural disasters (i.e. floods, wildfires) undermine development. There is a negative migratory balance between north-eastern governorates (Le Kef, Jendouba, Beja, and Siliana). Youth unemployment is very high mainly among university graduates.

In fact, social and cultural capitals play a key role in the social and urban inequalities phenomenon. The habitus as a system of long-lasting and transposable capacities (Bourdieu [13]) determines success or failure in education and society. Instead of developing justice and social equalities, the education system is a main factor of deepening social, and urban inequalities.

\section{Education enrolment disparities}

Women's unemployment reaches about $25.6 \%$ against $14.6 \%$ rate for men. On the higher education level, the more graduated women are the most exposed to 
Table 1: Youth unemployment in Tunisia. Source: http://i0.wp.com/wg.

\begin{tabular}{|l|c|c|c|c|c|}
\hline & $\begin{array}{c}15-19 \\
\text { years }\end{array}$ & $\begin{array}{c}20-24 \\
\text { years }\end{array}$ & $\begin{array}{c}25-29 \\
\text { years }\end{array}$ & $\begin{array}{c}15-29 \\
\text { years }\end{array}$ & $\begin{array}{c}30-34 \\
\text { years }\end{array}$ \\
\hline Tunis District & 52.8 & 52.2 & 31.9 & 36.7 & 18.5 \\
\hline North East & 40.5 & 36.7 & 29.0 & 33.7 & 19.6 \\
\hline North West & 50.0 & 43.8 & 37.2 & 41.5 & 19.6 \\
\hline Central East & 22.0 & 25.1 & 22.4 & 23.3 & 12.1 \\
\hline Central West & 61.7 & 63.2 & 52.4 & 57.9 & 31.8 \\
\hline South East & 48.0 & 53.1 & 45.8 & 48.6 & 26.1 \\
\hline South West & 60.2 & 60.5 & 53.8 & 56.5 & 24.8 \\
\hline Total & 43.6 & 41.8 & 34.5 & 38.2 & 19.0 \\
\hline
\end{tabular}

unemployment (43.5\%) in comparison to men (20.9\%) in the same year 2012. Gribaa and Depaoli [14, p. 4] pointed out on this issue: "Girls are less represented in: engineering diploma $(29 \%)$, architecture $(34.5 \%)$, veterinary medicine $(35.9 \%)$, physics sciences $(45.9 \%)$, informatics $(47.4 \%)$, and mathematics". But, women remain vulnerable to more unemployment, poverty, health, and economic risks. School enrolment and success rates vary throughout regions and delegations.

This soaring unemployment rate is an obvious indicator of the critical financial situation of the country. As we demonstrated in our recent research on territorial inequalities in Tunisia (Mahmoud [15]), Nation State failed to ensure fair urban planning. In fact, the deep gap between littoral areas and mainland persists. But note that even though in littoral areas of Tunisia, social inequalities exist between haves and have-nots (Boughzala and Tlili [16]).

Since the 1980s, regionalisation has been a mere framework for different development plans (Belhedi [17]). Only since the fifth development plan that the state undertook the regional dividing of the country to six or seven regions. Sboui [18, p. 62] pointed out: "in the 1980 s poor people represented about $52 \%$ of the Tunisian population. By the $2000 \mathrm{~s}$, in urban areas, the poverty rate $(52 \%)$ was higher than in rural ones. By 2005 the situation had reversed and the urban poverty rates decreased drastically by 3 points".

The paradox is that planning targets only regulation but not sustainable urban planning. Some institutions were created such as General Commissionership of Regional Development and proceeded to the creation of credit cards of Regional Development Plan, and afterwards Regional Plan of Integrated Development and the several Regional Development Plans along with The Office of Development of the North West (ODNW), and the Office of Development of the South (ODS); Office of Development of the Center West (ODCW)" (Belhedi [19]). The monoparty state led by Habib Bouguiba, and 'presidentialist' regime of Zine al Abidine ben Ali adopted a top-down economic, urban development, which begot the spatial inequalities. 


\section{Energy, the burning issues!}

The energy issue is in the core of the sustainable development. Tunisia had nearly achieved an energy sufficiency in the beginning of the third millennium. However, since 2005, a growing lack of energy resources had been observed. This decline has clearly accelerated from the year 2001, which urges us to wonder on the origin of this reduction (Hammamia [20]). Industries, transports, and real estate consume the lion's share of energy consumption in Tunisia. In fact, the energy intensity in the industrial sector decreased by $28 \%$ in 2008 with regard to its level in 1990s since its ration of energy consumption has decreased. However, it increased by $18 \%$ in the transport sector in 2008 . The energy sector in Tunisia is closely correlated to fossil energy consumptions. The atmospheric pollution of the neighbourhood stems from those materials combustion. The higher is the economic growth, the lesser is household's well-being improvement.

Table 2: Energy resources in Tunisia.

\begin{tabular}{|l|c|c|c|c|c|c|c|}
\hline Years & $\mathbf{1 9 8 7}$ & $\mathbf{1 9 9 1}$ & $\mathbf{1 9 9 5}$ & $\mathbf{1 9 9 9}$ & $\mathbf{2 0 0 3}$ & $\mathbf{2 0 0 5}$ & $\mathbf{2 0 0 6}$ \\
\hline Resources & 13984 & 6171 & 5283 & 6777 & 6379 & 6785 & 6442 \\
\hline Crude oil & 5109 & 5293 & 4343 & 4037 & 3230 & 3479 & 333 \\
\hline Natural gas & 850 & 855 & 931 & 2720 & 3105 & 3264 & 3080 \\
\hline Hydraulic and wind electricity & 25 & 23 & 9 & 20 & 44 & 42 & 29 \\
\hline Demand & 3638 & 4307 & 5391 & 6192 & 6964 & 7314 & 7411 \\
\hline Oil products & 2478 & 3442 & 3430 & 3724 & 3859 & 4017 & 4110 \\
\hline Natural gas & 1135 & 842 & 1952 & 2448 & 3043 & 3255 & 3272 \\
\hline Hydraulic and wind electricity & 25 & 23 & 9 & 20 & 44 & 42 & 29 \\
\hline Coke & & & & & 18 & 0 & 0 \\
\hline
\end{tabular}

The primary energy consumption had swiftly increased by 2013 (7947 Ktoe Kilotons of Oil Equivalent).

Abid et al. highlighted: "Given the dominance of industrial, transport and residential sectors in ultimate energy use, our descriptive as well as econometrical analyses will focus only on these three sectors. Moreover, we will consider that energy consumption depends only on the three basic components: oil, electricity, and natural gas because the other energy categories represent very small proportions and/or their consumption statistics are integrated in those of basic components" (Abid et al. [21, p. 23 and 57]).

Tunisia has many renewable energy resources. The report also argued that VLS-PVPS (Very Large Scale Photo Voltaic Power Systems) are not only technically and commercially feasible, but represent one of the most promising 
solar energy solutions. In desert regions (Kebili, Tataouine) in the South of Tunisia many sustainable energy opportunities such as natural gas extraction and solar plants could be implemented. Tunisian State will soon undertake a partnership within an institutional and research framework. Local inputs are importantly available, but energy good governance has been lacking.

\subsection{How to meet the growing demand of energy in Tunisia}

Due to population growth and increasing affluence, the total electricity consumption as well as the per capita consumption in Tunisia has increased over the last decade. If either was limited, the energy resources cannot fulfil Tunisian energy needs for the economy and society.

In the year 2010, electricity sales, by STEG (Electric and Gas Tunisian Company) increased by $6.2 \%$ from $12,254 \mathrm{GWh}$ in 2009 to $13,015 \mathrm{GWh}$ in 2010. Peaks occurred during summer afternoons because of air conditioning overuse, which threatens the electricity supply capacity. Some experts speculate that by 2016, Tunisia will face severe shortages of electricity in the summer unless new power plants are constructed.

In addition, a cheap and stable supply of electricity is important to promote economic growth. After the revolution, cheap electricity plays an important role in jobs supplies. For example, STEG owns and operates nine wind farms in Tunisia. However, these turbines are not effectively used to their full potential because of their location - a suitable location where there is a constant wind supply, and more importantly across urban settlement and hence disturbs inhabitants from the noise they cause.

As far as renewable energies are concerned in Tunisia, Ito argued in this issue: "The Tunisian government subsidises imported natural gas in order to make electricity costs low for end users. However, this puts financial pressure on the state's budget. The policy supports Algerian exporters and creates a dependency on these exports. Furthermore, electricity generated by other methods has to compete with subsidised gas prices. As a result, this provides a disincentive for installing one's own residential solar panels or investing in power plants" (Ito [22, p. 19]).

Some shale gas deposits were discovered in Kairouan and Kasserine governorates (Center of Tunisia), but civil society and public opinion is opposed to its extraction. However, because of potential environmental risks, some experts warn that drilling of shale gas introduces carcinogenic waste into the environment, and nearby water supplies.

\section{Conclusion remarks}

Sustainable urban development in post-revolutionary Tunisia is facing a myriad of challenges. Spatial and territorial inequalities could hamper the democratic transition process. Many social, economic, and cultural aliases such as terrorism, informal activities, and ecological syndrome constitute resilience to sustainable 
urban governance implementation. Previous urban development policies undertaken since independency entailed a deep gap between coastal regions and hinterland. As a subsystem within a global economic system (Wallerstein [23]), the Tunisian economy and society developed amongst a liberal and new liberal economics, and 'bisectorial economy' of formal and informal sectors is not conceivable in a mere dual approach. Both sectors blur and interfere within a networked world economy that transcends national edges to interconnect with global urban nodes (i.e. New York, Tokyo, and London) and megapolises in Europe, America, Middle East, and China.

The top down policy makings followed by Tunisian State since independency deepened instead of reducing inequalities, they entailed economic, urban gaps and spatial inequalities.

In order to mitigate those spatial and social disparities, and injustices, Tunisian State had put in place some urban planning institution framework that benefitted - economic world competitiveness obliged - more the littoral areas. The decreed parcelling out documents (e.g. Urbanism Code, Urban Planning Plans and Schemas of Urban Planning Master Plans) were conceived and achieved through top-down policy makings. Poverty and social exclusion were so acute in the central areas of the country (i.e. Sidi Bou Zid, and Kasserine) that uprising had grown since 2008 and begot the December 17, 2010, and January 14, 2011 revolution. Even though, the quartet and civil society succeeded to draft a new democratic constitution and fair democratic election, social and territorial inequalities persist between coastal and interior areas and between towns, rural areas, and between the better-off and the less well-off. Middle classes downsized to the lowest level of their living standing.

Hence, those urban and social biases could hamper the democratic process. The growing smuggling traffic linked to the rise of terrorist acts targeting new nation-state are serious challenges against the democratic process and economic recovery in Tunisia. New elected rulers have to achieve people expectations by ensuring security, and implementing a new sustainable urban planning in accordance with Tunisia revolution objectives (i.e., freedom, dignity and justice).

Energy sectors matter too much in economic development of Tunisia. The country lacks energy resources, and has many renewable energy opportunities. However, those resources exploitation depend on good governance in this very sensible sector depending on national and supra national stakeholders who are competing in this issue. Energy intensity exploitation and seeking for new renewable ones are in the core of a sustainable social and territorial development. This development strategy requires that social and urban actors rely on local democracy strategies based on their social and cultural contexts; a bottom up policy making shouldn't deny the top down state role in public spending and fair taxations policies. The new ruling majority government of the main civic and modernist party Nidaa Tounes has to rule the country, not alone, and according multilevel governance (Gonzelman [24]) for a sustainable urban planning with fairness, accountability, and justice. 


\section{References}

[1] Soja, W. E., The city and spatial justice, Paper prepared for presentation at the conference Spatial Justice, Nanterre, Paris, March 12-14, 2008. http://www.jssj.org/wp-content/uploads/2012/12/JSSJ1-1en4.pdf retrieved on Friday October 242014 at 22:52.

[2] Stiglitz, J., The Price of Inequality, New York: Allen Lane an imprint of Penguin Books, 2012, 414 pages.

[3] Marcuse, H., One-Dimensional Man: Studies in the Ideology of Advanced Industrial Society, 1964. http://www.marxists.org/reference/archive/ marcuse/works/one-dimensional-man/one-dimensional-man.pdf retrieved on Sunday 12 October 2014 at 8:24.

[4] Stiglitz, J. et al., Report by the Commission on the Measurement of Economic Performance and Social Progress www.stiglitz-sen-fitoussi.fr retrieved on Tuesday June 272009 at 16:13.

[5] Kriaa, M. et al., Multidimensional inequalities in Tunisia, 2011. http://www.erf.org.eg/CMS/uploads/pdf/Driss\%20Kriaa\%20\&\%20Karray. pdf retrieved on Sunday May 312014 at 21:47.

[6] Belhedi, A., "Le rayonnement spatial des villes tunisiennes à travers la diffusion des entreprises multi-établissements pour l'innovation", Cybergeo: European Journal of Geography (En ligne), Espace, Société, Territoire, document 372, mis en ligne le 16 avril 2007, consulté le 23 mai 2015. URL: http://cybergeo.revues.org/5607; DOI: 10.4000/cybergeo.5607.

[7] Dlala, H. et al., Mondialisation et Changement Urbain, Manouba: University Press Center, 2010, 309.

[8] Marcuse, P. et al., City for People, Not for Profit: critical urban theory and the right to the city, Routledge, 296 pages, 2012.

[9] Balandier, G., Le Désordre, éloge du Mouvement, Paris: Fayard, 1988, 252 pages.

[10] Boubakri, H., and Nouri, H., Migrations, transformations sociales et recompositions des territoires dans la Jeffara (Sud-Est de la Tunisie) in: Développement rural, Environnement et Enjeux territoriaux Regards croisés Oriental marocain et Sud-Est, Tunis: Cérès Editions tunisien, 2009. http://horizon.documentation.ird.fr/exl-doc/pleins_textes/divers1307/010050194.pdf accessed on Friday March 7th 2014 at 9:53.

[11] Kartas, M., On the Edges? Trafficking and Insecurity at the TunisianLibyan Borders. http://www.smallarmssurvey.org/fileadmin/docs/FWorking-papers/SAS-WP17-Tunisia-On-the-Edge.pdf, 2013 accessed on Thursday 62014 at 20:45.

[12] UN-Habitat. The State of World cities: prosperity of cities, 2012-2013. http://mirror.unhabitat.org/pmss/listItemDetails.aspx?publicationID=3387 retrieved on Sunday 6 July 2014 at 7:46. 
[13] Bourdieu, P., The Logic of Practice, California: Stanford University Press, 1990, 333 pages.

[14] Gribaa, B. and Depaoli, G., Profil genre de la Tunisie. Document rédigé dans le cadre de la mission d'identification d'un programme de promotion de l'égalité homme-femme en Tunisie financé par L'union EuropéenneVersion Courte, 2014. http://eeas.europa.eu/delegations/tunisia/ documents/page_content/profil_genre_tunisie2014_courte_fr.pdf accessed on Saturday, October 25, 2014 at 19:57.

[15] Mahmoud, A., Territorial and Social Inequalities in Tunisia, which sustainable urban governance? In: Review of Research, Vol. 3, Issue 5, Feb. 2014.

[16] Boughzala, M., and Tlili M. H., Promoting inclusive growth in Arab countries: rural and regional development and inequality in Tunisia, 2014. http://www.brookings.edu/ /media/research/files/papers/2014/02/promotin g\%20growth\%20arab\%20countries/arab\%20econpaper5boughzala\%20v3. pdf accessed on Friday 17 July 2014 at 17:07.

[17] Belhedi, A., the Tunisian Urban System. Demographic and functional hierarchical analysis based on the Rank-Size Rule, 2004. http://cybergeo.revues.org/3877 accessed on Sunday October 122014 at 9:02.

[18] Sboui, F., Effect of growth and inequality on poverty in Tunisia. In: Région et Développement, No 35, 2012. http://regiondeveloppement.univ-tln.fr/fr/pdf/R35/4_SBOUI-1.pdf accessed on Friday, October 2014 at 6:23.

[19] Belhedi, A. Différenciation et Recomposition de l'Espace Urbain en Tunisie Cahiers du GREMAMO, $\mathrm{n}^{\circ} 18$ Laboratoire SEDET-CNRS Denis Diderot, Université Paris VII (France), 266 pp L'Harmattan, Paris, 2005. http://archive.today/OOiQb retrieved on Sunday May 312014 at 22:30.

[20] Hammamia, A. Analysis of the Decomposition of Energy Intensity in Tunisia. In: International Journal of Energy Economics and Policy Vol. 4, No. 3, 2014, pp. 420-426 ISSN: 2146-4553. www.econjournals.com. http://www.econjournals.com/index.php/ijeep/article/view/829/478 accessed on Friday October 242014 at 5:42.

[21] Abid, M. et al. Energy Consumption-Economic Growth Nexus: Does the Level of Aggregation Matter? In: International Journal of Energy Economics and Policy Vol. 2, No. 2, 2012, pp. 55-62 ISSN: 2146-4553. www.econjournals.com accessed on Wednesday 9 July 2014 at 9:42.

[22] Ito, H., Renewable Energy in Tunisia, Working Paper, 2013. http://policyleadershipinstitute.org/documents/RENEWABLE\%20ENERG Y\%20IN\%20TUNISIA\%20-\%20IPLI\%20Working\%20Paper\%20\%20Hiroyuki\%20Ito.pdf accessed on Wednesday July 92014 at 7:42.

[23] Wallerstein, I. Special Symposium on the modern world system. In: Contemporary Sociology: A Journal of Reviews-2012-Wallerstein-6-9 American Sociological Association 2012. http://fr.scribd.com/doc/ 217937288/Contemporary-Sociology-A-Journal-of-Reviews-2012Wallerstein-6-9 accessed on Sunday April 202014 at 6:42. 
46 The Sustainable City X

[24] Gonzelman, R., towards a new concept of multi-level governance? Remarks by Dr. Thomas Conzelman, University of Maastricht MLG Atelier, 10 September. (Revised version: 25 September 2008). http://cor.europa.eu/en/activities/governance/documents/Conzelmann.pdf retrieved on Wednesday August 302014 at 6:46. 